\title{
Perturbation of liver function markers and serum electrolytes associated with Echinococcus granulosus infection in sheep
}

\author{
I.F. Ali ${ }^{\circ}$ and T.W. Jihad $\odot$ \\ Department of Biology, College of Education for Pure Science, University of Mosul, Mosul, Iraq
}

\begin{tabular}{l} 
Article information \\
\hline Article history: \\
Received December 06, 2020 \\
Accepted April 16, 2021 \\
Available online November 19, 2021 \\
\hline Keywords: \\
Echinococcus granulosus \\
Electrolytes \\
Hydatid cysts \\
Infection ratio \\
Liver \\
\hline Correspondence: \\
I.F. Ali \\
ibrahimfali@uomosul.edu.iq
\end{tabular}

\begin{abstract}
Histopathological alterations in the liver of intermediated hosts infected with Echinococcus granulosus parasite can be occurred by necrotic expansion as a result of an increase in growth of the parasite larva stage (metacestode), which may cause perturbation in production of liver function markers. Thus, this study aims to determinate the liver biochemical profile and some serum electrolytes of E. granulosus-infected sheep at different hydatid cyst infection ratios (IRs). fifty livers from naturally E. granulosusinfected sheep with five livers from uninfected-sheep as a control group were enrolled in this study. Cardiac blood samples under sterilized conditions were gently collected and isolated sera were biochemically assayed for determination of liver function markers including; Aspartate transaminase (AST), Alanine transaminase (ALT), alkaline phosphatase (ALP), Albumin (ALB) and total protein (TP), as well as the level of some serum electrolytes including $\mathrm{Ca}, \mathrm{K}, \mathrm{Na}$ and $\mathrm{Cl}$ using fully automatic biochemical analyzer, FUJI-Film. The current data indicated a progressive increase in the level of AST, ALT, ALP, Ca and K. The level of ALB and TP were gradually declined with a rise of liver infection ratio with hydatid cysts. In conclusion, the current findings indicated perturbation of liver function markers and the level of some serum electrolytes, mainly $\mathrm{Ca}$ and $\mathrm{K}$ in E. granulosus-infected sheep based on the infection ratio of liver. Additionally, acute and chronic infection of E. granulosus parasites in sheep can be determined based on the level of liver function markers in serum.
\end{abstract}

DOI: 10.33899/ijvs.2021.128926.1624, (A)Authors, 2022, College of Veterinary Medicine, University of Mosul.

This is an open access article under the CC BY 4.0 license (http://creativecommons.org/licenses/by/4.0/).

\section{Introduction}

Echinococcosis is a parasitic disease caused by the $E$. granulosus parasite's larva stage in intermediate hosts, including humans and other warm-blooded vertebrates. Morphologically, the disease can be recognized as multiple hydatid cysts within different internal organs of infected host particularly in the liver (1). The disease represents a real global challenge against health and economic development, especially in the third world states, due to lack of critical health care in humans and dogs, as well as large numbers of wild dogs that live near to the human communities which increase the infection risk. Thus, direct and indirect depletion of manpower and livestock can threat the economy in many countries around the world by echinococcosis disease (2). Delay or accidental diagnosis of expanded hydatid cysts can increase disease complications and reduce the probability of the complete healing. Asymptomatic growth and distribution of hydatid cysts in the host body increase disease fight challenges (3). The necrotic cell death that occurred around the E. granulosus larva stage (metacestode) by host cell lysis is an action of parasite development (4), by which provides enough space for expanding of hydatid cysts (5). Moreover, histopathological changes that occur from the mass expansion of hydatid cysts cause pressure on the surrounding host tissues, in which may have 
pathophysiological effects on the infected organs. Although, liver is the mean organ that produce AST, ALT and ALP, many organs including; pancreas and kidney as well as different cells such as red blood cells and muscular cells, can produce these enzymes but at lower levels (6). Recently, level of AST and ALT, known as glutamic oxaloacetic transaminase (GOT) and glutamic pyruvic transaminase (GPT), respectively, in the serum were reported to be early specific markers of liver damage even before symptoms onset (7). Histopathologically, the slight hemorrhage, white blood cells (WBCs) infiltration and denaturation of hepatocytes are the most frequent features of livers infected with the metacestode stage of $E$. granulosus (8). The liver is an essential organ that produce a range of enzymes and participates in detoxification (9).

Thus, this study aimed to evaluate the alteration of liver function markers and some serum electrolytes in $E$. granulosus-infected sheep, which may reflect the level of liver damage at different infection ratios of the liver and may support the radiological diagnosis. Additionally, this may also allow to biochemical tracing of parasite infection and determination intensity of parasites.

\section{Materials and methods}

\section{Blood samples and biochemical analysis}

For cardiac blood collection, hearts and livers were removed from E. granulosus-infected and uninfected sheep slaughtered by butchers in the open sheep market in Mosul city, north of Iraq. Followed by sterilization of heart surface using $70 \%$ ethanol and direct gently aspiration of blood from the heart to avoid blood agglutination. The cardiac blood samples were kept in 10 $\mathrm{mL}$ test tubes and transferred to the research laboratory building in the College of Education for Pure Science/ Mosul University to be assayed for liver biochemical profile and serum electrolytes determination. The liver biochemical markers including AST, ALT, ALP, ALB and $\mathrm{TP}$ as well as some serum electrolytes including $\mathrm{Ca}, \mathrm{K}, \mathrm{Na}$ and $\mathrm{Cl}$ of E. granulosus-infected sheep at different liver infection ratios were determined versus the control group using a fully automatic biochemical analyzer, FUJI-Film, (DRI-CHEM NX500 - Fujifilm, Tokyo, Japan).

\section{Calculation of hydatid cyst infection ratio (IR) of liver}

The weight of hydatid cysts and liver were precisely measured using a digital milligram scale. The hydatid infection ratio of livers was measured by dividing the weights of a single liver's hydatid cysts of on whole weight of infected liver and times by hundred. Hydatid cyst infection ratio of liver $=$ Weights of Single liver's hydatid cysts/ Whole weight of infected liver $* 100$.

\section{Statistical analysis}

The data of liver biochemical markers in the serum including AST, ALT, ALP, ALB, TP and some serum electrolytes of E. granulosus-infected and uninfected sheep were statistically analyzed by One-Way ANOVA, with Dunnett post-test formulation using GraphPad Prism 5.0 software (GraphPad Software, Inc., San Diego, California, USA). The probability value (P-value) of variation between variables were calculated and considered to be significant $*, * *, * * *$ at $\mathrm{P}<0.05,0.01$ and 0.001 , respectively.

\section{Results}

This study is originally established to investigate the impact of transmission and mass growth of the metacestode stage (hydatid cysts) of E. granulosus parasite in the liver on the liver biochemical profile and some serum electrolytes. The main liver biochemical markers including AST, ALT, ALP, ALB and TP, a well as some serum electrolytes including; $\mathrm{Ca}, \mathrm{K}, \mathrm{Na}$ and $\mathrm{Cl}$ levels were investigated. The data of liver enzyme profile indicated a significant increase $(p<0.01)$ in the level of AST, ALT

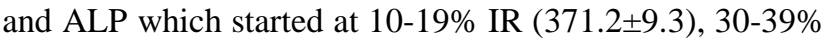
IR (209.66 \pm 8.38$)$ and $40-49 \%$ IR (406.66 \pm 11.59$)$, compared to the control group which reported (91.2 \pm 9.8$)$, (23.2 \pm 9.2$),(80.2 \pm 12.6)$, respectively (Table 1$)$.

Table 1: The level (mean \pm SD) of AST, ALT, ALP, ALB and TP in serum of E. granulosus-infected and uninfected sheep (control) at different hydatid cyst infection ratios (IR) of liver

\begin{tabular}{lccccc}
\hline Infection ratio (IR) & AST (U/L) & ALT (U/L) & ALP (U/L) & ALB (g/dl) & TP (g/dl) \\
\hline Control (n=5) & $91.2 \pm 9.8$ & $23.2 \pm 9.2$ & $80.2 \pm 12.6$ & $2.98 \pm 0.51$ & $6.56 \pm 0.65$ \\
10-19\% IR (n=8) & $371.2 \pm 9.3^{* *}$ & $68.5 \pm 6.24$ & $224.5 \pm 10.9$ & $1.6 \pm 0.6^{* *}$ & $4.45 \pm 1.08^{* *}$ \\
20-29\% IR (n=8) & $448.2 \pm 19.7 * * *$ & $91.75 \pm 9.11$ & $292.5 \pm 6.35$ & $2.5 \pm 0.49^{*}$ & $5.8 \pm 0.64^{*}$ \\
$30-39 \%$ IR (n=5) & $598.3 \pm 7.63 * * *$ & $209.66 \pm 8.38^{* *}$ & $256.66 \pm 9.6$ & $1.5 \pm 0.34^{* *}$ & $4.63 \pm 0.51^{* *}$ \\
$40-49 \%$ IR (n=6) & $922.33 \pm 9.45^{* * *}$ & $153.6 \pm 7.63^{*}$ & $406.66 \pm 11.59^{* *}$ & $2.43 \pm 0.41^{*}$ & $4.83 \pm 0.75^{*}$ \\
$50-59 \%$ IR (n=10) & $826.4 \pm 18.29^{* * *}$ & $374.8 \pm 16.6^{* * *}$ & $434.4 \pm 6.02^{* * *}$ & $1.8 \pm 0.31^{* *}$ & $2.7 \pm 0.69^{* * *}$ \\
$60-69 \%$ IR (n=6) & $961.6 \pm 10.4^{* * *}$ & $625.1 \pm 11.8^{* * *}$ & $670.33 \pm 10.6^{* * *}$ & $1.96 \pm 0.35^{*}$ & $2.36 \pm 0.37 * * *$ \\
$70-79 \%$ IR (n=7) & $996.33 \pm 6.3^{* * *}$ & $522 \pm 10.5^{* * *}$ & $563.3 \pm 8.96^{* * *}$ & $1.25 \pm 0.07 * * *$ & $2.7 \pm 0.81^{* * * *}$ \\
\hline
\end{tabular}

$*=P<0.05, * *=P<0.01, * * *=P<0.001, \mathrm{n}$ is the number of liver samples. 
Although, the serum level of ALB and TP in $E$. granulosus-infected sheep reported a significant decrease, starting at the early stage of infection in infected sheep comparing to uninfected sheep, but this decrease was fluctuated at different hydatid cyst infection ratios. The lowest level of ALB and TP were reported at 70-79\% IR and at $60-69 \%$ IR, respectively (Table 1). The serum electrolytic analysis data indicated noticeable and graduated increase in the levels of $\mathrm{Ca}$ and $\mathrm{K}$ in infected sheep compared to the control group. The significant increase in the levels of $\mathrm{Ca}$ and $\mathrm{K}$ were $7.57 \pm 2.7$ and $8.95 \pm 1.84$, respectively, where both started at $20-29 \%$ IR. Additionally, both $\mathrm{Ca}$ and $\mathrm{K}$ levels were reached to the highest significant values $12.86 \pm 0.91$ and $13.4 \pm 1.01$ at 60 $69 \%$ IR and $70-79 \%$ IR, in comparison to the control group which reported $4.84 \pm 0.57$ and $6.12 \pm 0.74$, respectively. The difference in the levels of $\mathrm{Na}$ and $\mathrm{Cl}$ between infected and uninfected sheep was not statistically taken into consideration, both electrolyte's level was relatively lower in infected sheep compared to uninfected group (Table 2).

Table 2: The level of some serum electrolytes including; $\mathrm{Ca}, \mathrm{K}, \mathrm{Na}$ and $\mathrm{Cl}$ of E. granulosus-infected and uninfected sheep (control) at different hydatid cyst infection ratios (IR) of the liver

\begin{tabular}{lcccc}
\hline Infection ratio (IR) & $\mathrm{Ca}(\mathrm{mg} / \mathrm{dl})$ & $\mathrm{K}(\mathrm{mEq} / \mathrm{L})$ & $\mathrm{Na}(\mathrm{mEq} / \mathrm{L})$ & $\mathrm{Cl}(\mathrm{mEq} / \mathrm{L})$ \\
\hline Control $(\mathrm{n}=5)$ & $4.84 \pm 0.57$ & $6.12 \pm 0.74$ & $137.40 \pm 8.73$ & $104.40 \pm 5.77$ \\
$10-19 \%$ IR (n=8) & $6.25 \pm 1.91$ & $8.50 \pm 1.63$ & $130.01 \pm 12.35$ & $99.75 \pm 11.75$ \\
$20-29 \%$ IR (n=8) & $7.57 \pm 2.7^{*}$ & $8.95 \pm 1.84^{*}$ & $134.04 \pm 14.16$ & $101.03 \pm 8.16$ \\
$30-39 \%$ IR (n=5) & $8.16 \pm 1.05^{*}$ & $10.16 \pm 0.61^{* *}$ & $127.66 \pm 19.13$ & $95.53 \pm 13.92$ \\
$40-49 \%$ IR (n=6) & $9.60 \pm 1.21^{* *}$ & $13.10 \pm 0.88^{* * *}$ & $132.02 \pm 11.7$ & $100.33 \pm 7.02$ \\
$50-59 \%$ IR (n=10) & $10.72 \pm 0.73^{* * *}$ & $11.90 \pm 1.59^{* * *}$ & $107.01 \pm 9.51^{*}$ & $92.80 \pm 9.54$ \\
$60-69 \%$ IR (n=6) & $12.86 \pm 0.91^{* * *}$ & $11.46 \pm 1.20^{* * *}$ & $118.66 \pm 9.01$ & $90.66 \pm 11.05$ \\
$70-79 \%$ IR (n=7) & $12.13 \pm 0.75^{* * *}$ & $13.40 \pm 1.01^{* * *}$ & $125.33 \pm 7.02$ & $94.67 \pm 7.01$ \\
\hline
\end{tabular}

$*=P<0.05, * *=P<0.01, * * *=P<0.001, \mathrm{n}$ is the number of liver samples

\section{Discussion}

Liver metastasis occurs in the chronic stage of various liver diseases such as cancer, hepatitis (10) cirrhosis (11) and fasciolosis which may impact on the liver functions (12). The liver function markers including, AST and ALT which shown in the current study are comparable to data that obtained previously in the liver fibrosis cases (13). In clinical study of cystic echinococcosis, biochemical analysis of 49 individuals showed an increase in the serum level of AST, ALT and ALP in $26.4 \%, 24.5 \%$ and $35.8 \%$ of the cases, respectively (14). The serum level of AST and ALT can be considered as biochemical markers of liver function, where an increase of their levels refers to damage occurring in the liver cells $(15,16)$. An increase of AST, ALT, ALP, and GGT level in the report case of Fasciola hepatica-infected woman was identified (17). This data is agrees with the data that obtained in the current study, where ALT level dramatically increased with an increase in the level of liver's level of hydatid cyst infection ratio. The oxidative damage in the mice liver tissues induced by glyphosate was accompanied by an increase in the serum level of AST and ALT (18). The abnormality of liver enzyme levels may indicate liver damage at different stages of infection, where in chronic stage of viral hepatitis, the liver enzymes, in particular AST and ALT levels were increased (19). Moreover, in case of colestatic hepatitis of Cytomegalovirus-infected infants, the level of AST and ALT concentrations were dramatically higher than the serum normal range of healthy individuals (20). In another related study on parasitic tapeworms, no obvious correlation was reported between liver AST level and infection with tapeworm Khawia armeniaca in fish host (21).

In partial matching to the current data, production of circulating proteins that are synthetized by the liver, such as ALB and clotting factors, were dramatically reduced in chronic liver diseases (22). Alteration in serum levels of ALB and TP during various liver diseases were previously determined, where low serum level of ALB and TP in infected sheep may be due to concentrating these elements in hydatid cyst fluid and protoscoleces (23) or may be related to the effect of expanded hydatid cysts on protein secretion from the liver (24). Thus, the graduated reduction in ALB and TP levels that are indicated in the current study seems to be associated with an increase in liver's hydatid cyst infection ratio, which may be caused by expand growing of hydatid cysts in the liver. In agreement with the current data, during endoparasitic infections such as hydatid cysts and Dicrocoelium dendriticum infection, high plasma levels of liver enzymes such as AST and ALT with low level of TP and vitamin-A were determined (25).

Generally, successful infection of a pathogen is based on the immune status of the host and nutrition available, including the main elements and minerals (26). The importance of minerals in the maintenance of normal physiological functions of organs and protection the organisms from diseases were previously reported, where some of the minerals are involved in the structure of enzymes or serve as cofactors that participate in enzymes' 
activity (27). In the current study, a significant increase in the level of some serum electrolytes such as $\mathrm{Ca}$ and $\mathrm{K}$ may indicate the importance of these elements in host-parasite interaction, where $\mathrm{Ca}$ ions involve in the activation of calmodulin protein (Ca-binding protein) which is highly expressed in protoscoleces and the germinal layer of $E$. granulosus (28). The importance of calmodulin is reported to be as a critical protein in the Ca signaling pathway, mitochondria events, gene expression and it involves in calmodulin-dependent kinase activities (29). As shown previously, the high concentration of $\mathrm{Na}$ and $\mathrm{Cl}$ in hydatid cyst fluid may interpret decrease their levels in the serum of infected sheep as shown in the current study (30). It has been indicated that $\mathrm{Na}$ level in hydatid cyst fluid higher than the level of $\mathrm{Ca}$ and $\mathrm{K}$ by more than 12 and 6 times, respectively, in which can be suggested that accumulation of $\mathrm{Na}$ in hydatid cyst fluid at high concentration lead to reduce its level in the serum as shown in the current study (31).

\section{Conclusion}

Serum biochemical parameters including; liver enzymes (AST, ALT and ALP) and liver-secreted proteins (ALB and $\mathrm{TP}$ ), as well as some serum electrolytes such as $\mathrm{Ca}$ and $\mathrm{K}$ can be used as biochemical indicators of liver infection ratio or liver damage caused by E. granulosus parasites. This can be dependent as complementary indicators which may support the radiological diagnosis of hydatid disease. Additionally, early and chronic infection of the liver with $E$. granulosus can be determined based on the level of liver function markers in particular AST, ALT and ALP.

\section{Acknowledgment}

The authors would like to acknowledge the University of Mosul, College of Education and Pure Science/ Department of Biology for kind assistance by providing easy access to facilities and equipment.

\section{Conflicts of interests}

The authors declare no conflict of interests.

\section{References}

1. Lv H, Jiang Y, Liu G, Zhang S, Peng X. Surgical treatment of multiple hydatid cysts in the liver of a pediatric patient. Am J Trop Med Hyg. 2015;92:595-598. DOI: 10.4269/ajtmh.14-0445

2. Budke CM, Deplazes P, Torgerson, PR. Global socioeconomic impact of cystic echinococcosis. Emerg Infect Dis. 2006;12:296-303. DOI: 10.3201/eid1202.050499

3. Torgerson PR, Budke, CM. Echinococcosis: An international public health challenge. Res Vet Sci. 2003;74:191-202. DOI: 10.1016/S0034-5288(03)00006-7

4. Beigh AB, Darzi MM, Bashir S, Shah A, Shah SA. Gross and histopathological alterations associated with cystic echinococcosis in small ruminants. J Parasit Dis. 2017;41:1028-103. DOI: 10.1007/s12639-017-0929-Z

5. Miman O, Atambay M, Aydin NE, Daldal N. Necrosis in human cystic echinococcosis: An under recognized tissue reaction possibly related to host response. Turk J Med Sci. 2009;39:203-207. DOI: 10.3906/sag-0804-22

6. Derbel F, Mabrouk MB, Hamida MBH, Mazhoud J, Youssef S, Ali AB, Jemni H, Mama N, Ibtissem H, Nadia A, El Ouni C. Hydatid cysts of the liver-diagnosis, complications and treatment. Abdom Surg. 2012;5:105-138. DOI: 10.5772/48433

7. Giannini EG, Testa R, Savarino V. Liver enzyme alteration: A guide for clinicians. CMAJ. 2005;172:367-379. DOI: $10.1503 / \mathrm{cmaj} .1040752$

8. Singh BB, Sharma R, Sharma JK, Mahajan V, Gill JPS. Histopathological changes associated with E. granulosus echinococcosis in food producing animals in Punjab (India). J Parasit Dis. 2016;40:997-1000. DOI: 10.1007/s12639-014-0622-4

9. Chiang JYL. Liver physiology: Metabolism and detoxification. In: McManus LM, Mitchell RN. Pathophysiology of human diseases. San Diego: Elsevier; 2014. 1770-1782 p.

10. Ringehan M, McKeating JA, Protzer U. Viral hepatitis and liver cancer. Philos Trans R Soc B Biol Sci. 2017;372:20160274. DOI: 10.1098/rstb.2016.0274

11. Chiou WY, Chang CM, Tseng KC, Hung SK, Lin HY, Chen YC, Su YC, Tseng CW, Tsai SJ, Lee MS, Li CY. Effect of liver cirrhosis on metastasis in colorectal cancer patients: A nationwide populationbased cohort study. Jap J Clin Oncol. 2015;45:160-168. DOI: 10.1093/jico /hyu178

12. Al-Mahmood SS, Al-Sabaawy HB. Fasciolosis: Grading the histopathological lesions in naturally infected bovine liver in Mosul city. Iraqi J Vet Sci. 2019;33:379-387. DOI: 10.33899/ijvs.2019.125546.1066

13. Ahmed Z, Ahmed U, Walayat S, Ren J, Martin DK, Moole H, Koppe $\mathrm{S}$, Yong S, Dhillon S. Liver function tests in identifying patients with liver disease. Clin Exp Gastroenterol. 2018;11:301-307. DOI: 10.2147/CEG.S160537

14. Joshi U, Subedi R, Jayswal A, Agrawal V. Clinical characteristics and management of the hydatid cyst of the liver: A study from a tertiary care center in Nepal. J Parasitol Res. 2020. 2020; 8867744. DOI: $10.1155 / 2020 / 8867744$

15. Celik I, Suzek H. The hematological effects of methyl parathion in rats. J Hazard Mater. 2008;153:1117-1121. DOI: 10.1016/j.jhazmat.2007.09.067

16. El-Demerdash FM, Yousef MI, Elagamy EI. Influence of paraquat, glyphosate and cadmium on the activity of some serum enzymes and protein electrophoretic behavior (in vitro). J Environ Sci Health B. 2001;36:29-42. DOI: 10.1081/PFC-100000914

17. Aminian K, Rezayat KA, Shafaghi A, Tanhaeevash R. Living Fasciola hepatica in biliary tree: A case report. Ann hepatol. 2012;11:395-398. DOI: 10.1016/S1665-2681(19)30937-8

18. Tang J, Hu P, Li Y, Win-Shwe TT, Li C. Ion imbalance is involved in the mechanisms of liver oxidative damage in rats exposed to glyphosate. Front Physiol. 2017;8:1083. DOI: 10.3389/fphys.2017.01083

19. Angulo P, Keach JC, Batts KP, Lindor KD. Independent predictors of liver fibrosis in patients with nonalcoholic steatohepatitis. Hepatol. 1999;30:1356-1362. DOI: 10.1002/hep.510300604

20. Campagna C, Bergamaschi R, Landini S, Bernardi F. Cholestatic hepatitis in infants with infection by perinatal CMV and deficiency rickets: Description of a case. Dig Liver Dis. 2013;45:e307. DOI: 10.1016/j.dld.2013.08.233

21. Al-Niaeemi BH, Dawood MH. Biomarkering metabolic activities of the tapeworm Khawia armeniaca (Cholodkovsky, 1915) in association to its fish host Barbus grypus (Hekle, 1843). Iraqi J Vet Sci. 2021;35:169-176. Dio:10.33899/ijvs.2020.126518.1339

22. Mezey E. Liver Disease and protein needs. Annu Rev Nut. 1982;2: 21-50. DOI: 10.1146/annurev.nu.02.070182.000321

23. Frayha GJ, Haddad R. Comparative chemical composition of protoscolices and hydatid cyst fluid of Echinococcus granulosus 
(Cestoda). Int J Parasitol. 1980;10:359-364. Doi. 10.1016/00207519(80)90036-3

24. Hasona NA, Amer OH, Morsi A, Raef A. Comparative biochemical, parasitological, and histopathological studies on cystic echinococcosis in infected sheep. Comp Clin Pathol. 2017;26:805-810. DOI: 10.1007/s00580-017-2450-2

25. Cinar M, Aydenizoz M, Gokpinar S, Camkerten C. Evaluation of biochemical parameters and oxidative stress in sheep naturally infected with Dicrocoelium dendriticum and hydatid cysts. Turk J Vet Anim Sci. 2018;42:423-428. DOI: 10.3906/vet-1707-80

26. Pereira PC. Interaction between infection, nutrition and immunity in tropical medicine. J Venom Anim Toxins Incl Trop Dis. 2003;9:163173. DOI: $10.1590 / \mathrm{S} 1678-91992003000200003$

27. Speich M, Pineau A, Ballereau F. Minerals, trace elements and related biological variables in athletes and during physical activity. Clin Chim Acta. 2001;312:1-11. DOI: 10.1016/S0009-8981(01)00598-8

28. Wang N, Zhong X, Song X, Gu X, Lai W, Xie Y, Peng X, Yang G. Molecular and biochemical characterization of calmodulin from Echinococcus granulosus. Parasit vectors. 2017;10:597. DOI: 10.1186/s13071-017-2545-2

29. Dick IE, Tadross MR, Liang H, Tay LH, Yang W, Yue DT. A modular switch for spatial $\mathrm{Ca}^{2+}$ selectivity in the calmodulin regulation of $\mathrm{CaV}$ channels. Nature. 2008;451:830-834. DOI: 10.1038/nature06529

30. Muhsin SS, Mohsin MA, Hossien YK. Analysis of chemical component of hydatid fluid in infected sheep with Echinecoccus granulosus. J Nurs Health Sci. 2015;4: 64-67. DOI: 10.9790/195904616467

31. Juyi L, Yan J, Xiufang W, Zhaoqing Z, Junliang L, Mingxing Z, Wei $Z$. Analysis of the chemical components of hydatid fluid from Echinococcus granulosus. Rev Soc Bras Med Trop. 2013;46:605-610. DOI: $\underline{10.1590 / 0037-8682-0154-2013}$

\section{اضطراب مؤشرات وظائف الكبا والكتروليتات المصل المرتبطة بعدوى المشوكة الحبيبية والفئية في الأغنام}

إبراهيم فارس علي و تمارا وليا جهاد

فرع علوم حياة، كلية التربية للعلوم الصرفة، جامعة الموصل،

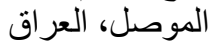

الخلاصة

يمكن أن تحدث التغيرات النسجية المرضية في كبد المضائف

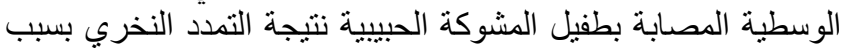

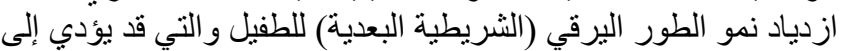

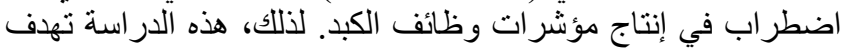
إلى تحديد الصورة الكيموحيوية للكبد وبعض التوات الالكتروليتات للأغنام

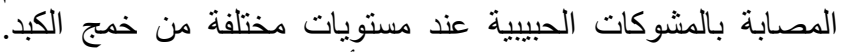

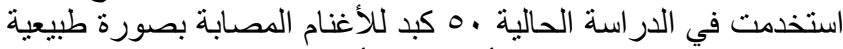

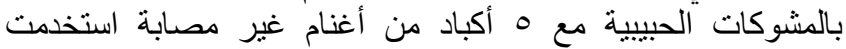

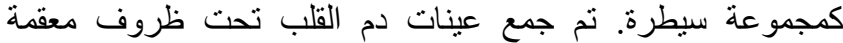
والأمصال المعزولة تم فحصها باختبار ات الكيمياء الحياتية لتحديد

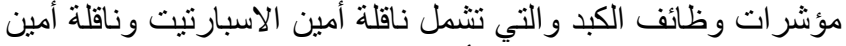

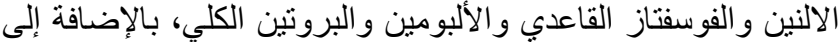

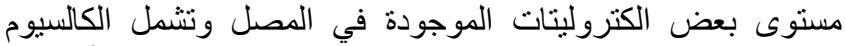

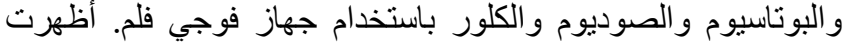
النتائج الحالية زيادة تدريجية في مستوى ناقلة أمين الاسبارنيت وناقيت وناقلة

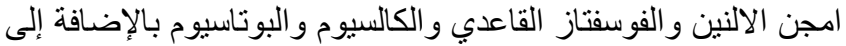

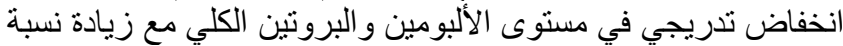

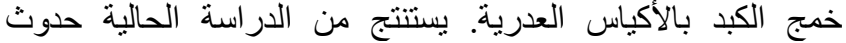

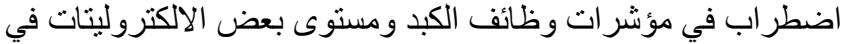

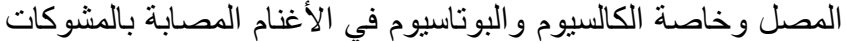

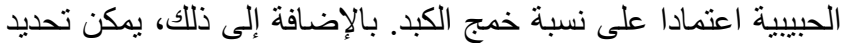
الإصـابة الحادة و الإصـابة المزمنة بطفيل المشوكات المات الحبيبية في الأغنام بالاعتماد على مستوى مؤشرات وظائف الكبد في المصل. ولهن 